\title{
Homolytic Cleavages in Pyridinium Ions, an Excited State Process
}

\author{
Chagit Denekamp, Elena Tenetov, and Yonit Horev \\ Department of Chemistry and Institute of Catalysis Science and Technology, \\ Technion-Israel Institute of Technology, Haifa, Israel
}

\begin{abstract}
The favored fragmentation pathway for protonated and alkylated pyridinium cations of the general formula $p-\mathrm{XC}_{6} \mathrm{H}_{4} \mathrm{CH}_{2} \mathrm{CH}_{2} \mathrm{CH}=\mathrm{CH} \mathrm{Py}^{+} \mathrm{R}(\mathrm{R}=\mathrm{H}$, Me; $\mathrm{Py}=$ pyridine $)$ is a $\mathrm{C}-\mathrm{C}$ homolytic cleavage. The tendency to form radicals is higher for alkylated pyridinium cations than for the protonated ones that can also afford closed-shell products. Theoretical calculations show that the singlet-triplet gap for transient structures with an elongated benzylic $\mathrm{C}-\mathrm{C}$ bond is very low and the formation of radicals may result from mixing of these states. In addition to the notable substituent effect on the fragmentation efficiency of the cations under study, calculated results show a clear substituent effect on the singlet-triplet transitions. We also observe that triphenylphosphonium cations behave notably different. Thus, the pyridinium system that contains a $p$-chloro benzyl moiety loses a benzyl radical readily while the analogous triphenylphosphonium cation is very stable under the same conditions. (J Am Soc Mass Spectrom 2003, 14, 790-801) (C 2003 American Society for Mass Spectrometry
\end{abstract}

$\mathrm{O}$ rganic closed shell ions typically dissociate into closed shell ionic and neutral products. Nevertheless, there are exceptions to this rule that may result from lack of selectivity under extremely energetic conditions, unusual stability of some cation radicals or specific kinetic effects. It is reasonable that highly energetic conditions promote simple bond cleavage, either heterolytic or homolytic. Some radicals, however are generated under mild conditions and their formation can only be attributed to their relative stability.

Different classes of organic closed-shell ions undergo $\mathrm{C}-\mathrm{C}$ and $\mathrm{C}-\mathrm{N}$ cleavages that are not necessarily charge driven [1-5]. Furthermore, it has been suggested that these reactions occur through a concerted mechanism or are mediated by the formation of radicals [6-9]. The development of electrospray ionization allowed the formation of various classes of closed shell ions under very mild conditions and hence it has been unambiguously shown that at least in some cases homolytic C-C and $\mathrm{C}-\mathrm{H}$ cleavages are involved in the gas phase decomposition of cationized organic compounds [10, 11].

One class of organic cations that are known to undergo homolytic cleavages is quaternary ammonium and pyridium cations $[8,12-17]$. Fisher and Veith studied the gas phase fragmentation of ammonium and pyridinium ions, generated with field desorption and

Published online June 4, 2003

Address reprint requests to Dr. C. Denekamp, Department of Chemistry and Institute of Catalysis Science and Technology, Technion-Israel Institute of Technology, Haifa 32000, Israel. E-mail: chchagit@tx.technion.ac.il reported the formation of nitrogen based radical cations under collision induced dissociation (CID) [12, 13]. Harrison showed that the formation of radicals and cations from quaternary ammonium ions is dominated by the relative ionization potential of the appropriate radicals and neutrals, showing that the reaction products are the ones thermodynamically favored [14, 15]. Katritzky and coworkers studied homolytic cleavages in pyridium cations that were designed in order to show the substituent effect on the relative stability of radicals. They propose the term "merostabilization" to describe stabilization that results from the presence of both an electron-attracting and an electron-donating substituent at the radical site. Thus, the formation of some pyridinium radical cations is rationalized using these arguments [16].

Formation of radicals may occur with the involvement of an electronically excited state. Hau et al. describes the formation of radicals from closed shell pyridinium cations with the involvement of a cation diradical [17]. Although not specified by the authors, such an intermediate may correspond to a triplet state. Vedernikova and coworkers propose that the different spin distribution in the excited state of lithium and sodium cationized esters is responsible for their different chemical behavior and support this proposal with high level ab initio calculations [18]. Voinov et al. corroborated the involvement of excited states in the high energy decomposition of free fatty acids by resonant electron capture experiments [9].

The singlet-triplet potential energy surface of several energetic intermediates was studied both experimentally and theoretically in order to determine the signif- 


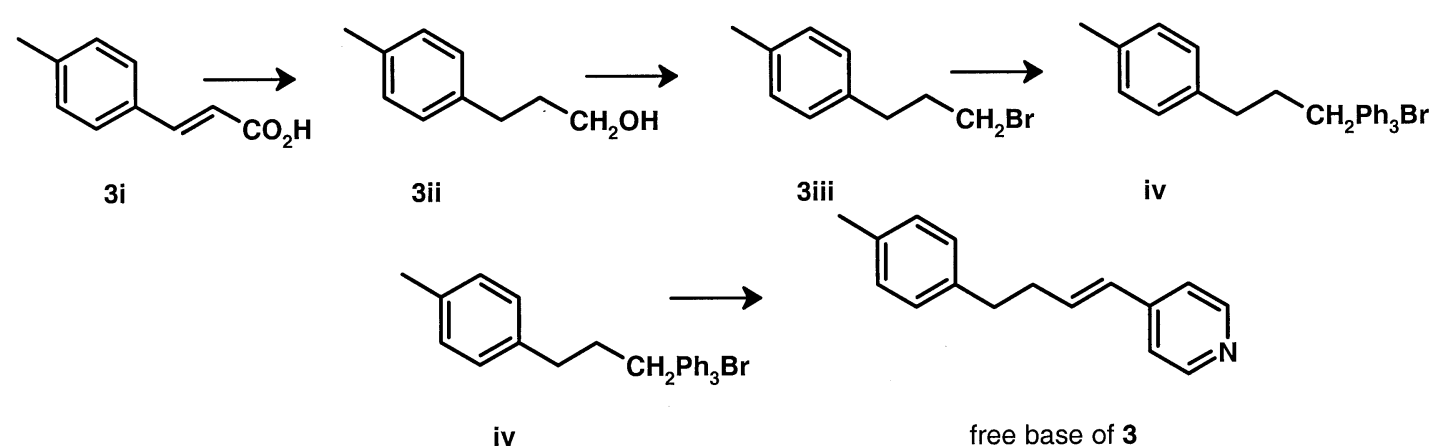

Scheme 1. General procedure for the preparation of the free bases of protonated pyridinium ions 1-5 and Wittig salts that correspond to the phosphonium cations 13-17.

icance of the triplet state in the description of these structures [19-23, 24-27]. Thus it was found that in the case of phenyl cation the singlet-triplet splitting is relatively small and with a right choice of substituents at the phenyl ring can even be reversed [19]. The geometry for the cross-point between singlet and triplet has been calculated as well as spin orbit coupling for this transient structure [20]. Other reactive intermediates that were extensively studied by Squires and coworkers are $o_{-}, m-$, and $p$ - isomeric benzyne anions [21-23]. The structure of all three benzyne ions was determined and their electron affinity was measured. Furthermore, the authors calculated the singlet and triplet energies of $o-, m$ - and $p$-benzyne and could show a singlet ground state for all three isomers. In this study it was found that density functional theory (DFT) is particularly well-suited for computational studies of these distonic radical anions [21].

We report here a study concerning the formation of pyridinium based radical cations from the corresponding closed-shell cations, both experimentally, upon CID and infrared multi-photon dissociation (IRMPD), and theoretically, applying DFT calculations.

\section{Experimental}

\section{Mass Spectrometry}

All ESI/FTICR experiments were carried out using Bruker BioAPEX III 47e FTICR spectrometer (Bruker Analytical Systems, Inc., Billerica, MA) equipped with a $4.7 \mathrm{~T}$ superconducting magnet, an external source (Apollo ESI Source), and an infinity analyzer cell. The samples were dissolved in 1:1 volume ratio of $\mathrm{CH}_{3} \mathrm{OH} /$ $\mathrm{CH}_{3} \mathrm{CN} / 0.01 \mathrm{mg} / \mathrm{ml}$ and introduced into the ESI source at a flow rate of $0.3 \mu 1 \mathrm{~min}^{-1}$. Ions were detected using the broadband detection mode covering a mass range from 50 to $5000 \mathrm{Da}$. Typically, eight individual transients were accumulated to improve the signal-tonoise ratio. Precursor ions were isolated using swept frequency ejection pulses of ca. $250 \mu$ s duration to eject all other ions. A pulsed valve introduced the argon collision gas prior to ion activation. With the pulsed valve open for $10 \mathrm{~ms}$ a peak pressure of $\sim 8$ exp-7 mbar was obtained. The precursor ions were excited using a variable amplitude resonance excitation pulse. Isolated ions were also activated using IRMPD, utilizing a $25 \mathrm{~W}$ continuous $\mathrm{CO}_{2}$ laser with output at $10.57-10.63 \mathrm{mi}-$ crons. The laser power was adjusted to $30-50 \%$ of maximal power with a duration irradiation period of $0.5-3 \mathrm{~s}$.

Fast atom bombardment experiments in combination with collision-induced dissociation measurements were carried out on a Finnigan TSQ-70B triple-stage quadrupole mass spectrometer. The scan rate was $1 \mathrm{scan} \mathrm{s}^{-1}$. CID measurements were performed with argon as the target gas (0.3 mTorr, indicated) at $10 \mathrm{eV}$ collision energy (indicated). All the data presented in each figure were obtained on the same day under identical conditions, in order to ensure reliable comparisons.

\section{Synthetic Preparation}

General procedures: ${ }^{1} \mathrm{H}$ NMR spectra were recorded at $200 \mathrm{MHz}$. All spectra were taken at ambient temperature, with the residual protons from the solvent as an internal reference and the chemical shifts are reported relative to TMS. Reagents and starting materials were used as supplied. The solvents were distilled and dried before use, if necessary, using standard methods. Merck silica gel 60 (230-400 mesh) was used for column chromatography. High resolution mass spectra were recorded for final products on a Bruker BioAPEX III 47e FTICR spectrometer.

1-(4-Methylphenyl)-4-(4-pyridyl)-butene-3 (free base of 3): 4-methylcinnamic acid (3i, Scheme 1 ) was prepared from $p$-tolualdehyde and malonic acid according to a literature procedure [28].

3-(4-Methylphenyl)-propane-1-ol (3ii): A solution of 4-methylcinnamic acid (6.6 g, $40.7 \mathrm{mmol})$ in $50 \mathrm{ml}$ THF was added dropwise to a suspension of $\mathrm{LiAlH}_{4}(2.61 \mathrm{~g}$, $68.7 \mathrm{mmol}$ ) in $50 \mathrm{ml}$ of THF at room temperature. After $0.5 \mathrm{~h}$ stirring the reaction mixture was quenched with 5 $\mathrm{ml}$ of water, dried over sodium sulfate and filtered. After solvent evaporation the residue was dissolved in $\mathrm{CH}_{2} \mathrm{Cl}_{2}$ and passed through a short silica column affording $5.5 \mathrm{~g}$ of the alcohol in $90 \%$ yield. ${ }^{1} \mathrm{H}$ NMR 
$\left(\mathrm{CDCl}_{3}\right) \delta=7.10(\mathrm{~s}, 4 \mathrm{H}), 3.66(\mathrm{t}, \mathrm{J}=6.4 \mathrm{~Hz}, 2 \mathrm{H}), 2.67(\mathrm{t}$, $\mathrm{J}=7.4,2 \mathrm{H}), 2.32(\mathrm{~s}, 3 \mathrm{H}), 1.87$ (quint, $2 \mathrm{H})$.

3-(4-Methylphenyl)-propyl-1-bromide (3iii): To a solution of $(7.4 \mathrm{~g}, 28 \mathrm{mmol})$ of triphenylphosphine in 30 $\mathrm{ml}$ of $\mathrm{CH}_{2} \mathrm{Cl}_{2}$ under argon at $0{ }^{\circ} \mathrm{C}$ was added $(4.48 \mathrm{~g}, 28$ $\mathrm{mmol}, 1.6 \mathrm{ml}$ ) of bromine. After removal of the ice bath, $(3.0 \mathrm{~g}, 20 \mathrm{mmol})$ of alcohol 3 ii were added during 20 min and the mixture was stirred at room temperature for $1 \mathrm{~h}$. The solvent was removed under reduced pressure and the residue was stirred with $50 \mathrm{ml}$ of ether, filtered through a thin pad of Celite, washed with saturated $\mathrm{NaHCO}_{3}$ and brine and dried over sodium sulfate. The solvent was removed under reduced pressure to afford 3iii $(3.9 \mathrm{~g}, 82 \%) .{ }^{1} \mathrm{H} \mathrm{NMR}\left(\mathrm{CDCl}_{3}\right) \delta: 7.10$ $(\mathrm{s}, 4 \mathrm{H}), 3.40(\mathrm{t}, \mathrm{J}=6.6 \mathrm{~Hz}, 2 \mathrm{H}), 2.74(\mathrm{t}, \mathrm{J}=7.3 \mathrm{~Hz}, 2 \mathrm{H})$, $2.33(\mathrm{~s}, 3 \mathrm{H}), 2.15(\mathrm{dt}, \mathrm{J}=6.9 \mathrm{~Hz}, \mathrm{~J}=7.2 \mathrm{~Hz}, 2 \mathrm{H})$.

3-(4-Methylphenyl)-propyl-1-triphenylphosphoniumbromide (iv): Triphenylphosphine $(5.19 \mathrm{~g}, 19.8 \mathrm{mmol})$ in $20 \mathrm{ml}$ of toluene was added to a solution of bromide (3iii) $(3.83 \mathrm{~g}, 18 \mathrm{mmol})$ in $50 \mathrm{ml}$ of toluene and the reaction mixture was refluxed for $48 \mathrm{~h}$. The resulting white precipitate was crystallized from $\mathrm{CH}_{2} \mathrm{Cl}_{2}$ - ethyl acetate, giving rise to $5.5 \mathrm{~g}(65 \%)$ white solid (mp 149-150 $\left.{ }^{\circ} \mathrm{C}\right) .{ }^{1} \mathrm{H}$ NMR $\left(\mathrm{CDCl}_{3}\right) \delta: 7.65(\mathrm{~m}, 15 \mathrm{H}), 7.04$ (s, $4 \mathrm{H}), 3.79(\mathrm{td}, \mathrm{J}=8.2 \mathrm{~Hz}, \mathrm{~J}=3.0 \mathrm{~Hz}, 2 \mathrm{H}), 2.93(\mathrm{t}, \mathrm{J}=7.2$ $\mathrm{Hz}, 2 \mathrm{H}), 2.26$ (s, 3H), 1.91 (quint, 2H).

4-[4-(4-Methylphenyl)-but-1-enyl]-pyridine (free base of 3): To a suspension of 3-(4-methylphenyl)propyl-1-triphenylphosphoniumbromide iv (1.7 $\mathrm{g}, 3.58$ $\mathrm{mmol}$ ) in $10 \mathrm{ml}$ of $\mathrm{THF}$ at $0{ }^{\circ} \mathrm{C}$ was added n-BuLi $1.6 \mathrm{M}$ in hexane $(2.3 \mathrm{ml}, 3.68 \mathrm{mmol})$; the resulting reddishorange solution was stirred at $0{ }^{\circ} \mathrm{C}$ for $20 \mathrm{~min}$, cooled to $-78{ }^{\circ} \mathrm{C}$ and pyridinecarboxaldehyde $(3.36 \mathrm{mmol}, 0.36 \mathrm{~g}$, $0.32 \mathrm{ml}$ ) in $5 \mathrm{ml}$ of $\mathrm{THF}$ was added dropwise. The reaction mixture was allowed to warm up to $0{ }^{\circ} \mathrm{C}$ and stirred for $2 \mathrm{~h}$. Then $3 \mathrm{ml}$ of $\mathrm{HCl} 2 \mathrm{~N}$ were added, the solvents were evaporated under reduced pressure and $10 \mathrm{ml}$ of $20 \% \mathrm{Na}_{2} \mathrm{CO}_{3}$ were added. After extraction with $\mathrm{CH}_{2} \mathrm{Cl}_{2}(20 \mathrm{ml})$ the organic layer was washed twice with brine, dried over sodium sulfate and the solvent was evaporated. The residue was purified by chromatography (silica gel, hexane-ethyl acetate, $0-25 \%$ of ethyl acetate) to afford the free base of $3 \mathrm{mp}$ (trans-isomer) 61-63 ${ }^{\circ} \mathrm{C}$. ${ }^{1} \mathrm{H}$ NMR $\left(\mathrm{CDCl}_{3}\right)$ : : trans-isomer-8.47 $(\mathrm{d}, \mathrm{J}=$ $5.9 \mathrm{~Hz}, 2 \mathrm{H}), 7.16(\mathrm{~d}, \mathrm{~J}=6.1 \mathrm{~Hz}), 7.09(\mathrm{~s}, 4 \mathrm{H}), 6.49(\mathrm{dt}, \mathrm{J}$ $=6.2 \mathrm{~Hz}, \mathrm{~J}=15.8 \mathrm{~Hz}, 1 \mathrm{H}), 6.31(\mathrm{~d}, \mathrm{~J}=16 \mathrm{~Hz}, 1 \mathrm{H}), 2.75$ ( $\mathrm{t}, \mathrm{J}=7.6 \mathrm{~Hz}, 2 \mathrm{H}$ ), 2.54 (quint, $\mathrm{J}=7.3 \mathrm{~Hz}, 2 \mathrm{H}$ ), 2.30 (s, $3 \mathrm{H}$ ). MS HR: $\mathrm{MH}^{+} m / z: 224.1433$ (calcd for $\mathrm{C}_{16} \mathrm{H}_{18} \mathrm{~N}$ 224.1434).

Pyridine free bases that correspond to protonated 2, 4 , and 5 were prepared in an analogous manner described for 3, starting from the substituted benzaldehydes and malonic acid.

4-[4-(4-Chloro-phenyl)-but-1-enyl]-pyridine (free base of 4$):{ }^{1} \mathrm{H}$ NMR $\left(\mathrm{CDCl}_{3}\right) \delta$ : trans-isomer- $8.47(\mathrm{~d}, \mathrm{~J}=$ $5.8 \mathrm{~Hz}, 2 \mathrm{H}), 7.24(\mathrm{~d}, \mathrm{~J}=8.3 \mathrm{~Hz}, 2 \mathrm{H}), 7.15$ (two doublets, $4 \mathrm{H}), 6.43(\mathrm{dt}, \mathrm{J}=6.5 \mathrm{~Hz}, \mathrm{~J}=9.4 \mathrm{~Hz}), 6.28(\mathrm{~d}, \mathrm{~J}=16 \mathrm{~Hz}$, $1 \mathrm{H}), 2.75(\mathrm{t}, \mathrm{J}=7.4 \mathrm{~Hz}, 2 \mathrm{H}), 2.52$ (quint, 2H). MS HR:
$\mathrm{MH}^{+}: m / z 244.0886$ (Calcd for $\mathrm{C}_{15} \mathrm{H}_{15} \mathrm{NCl}$ 244.0887), mp 79-80 ${ }^{\circ} \mathrm{C}$.

4-[4-(4-Trifluoromethylphenyl)-but-1-enyl]-pyridine (free base of 5): ${ }^{1} \mathrm{H}$ NMR $\left(\mathrm{CDCl}_{3}\right) \delta$ : trans-isomer: 8.49 $(\mathrm{d}, \mathrm{J}=5.4 \mathrm{~Hz}, 2 \mathrm{H}), 7.53(\mathrm{~d}, \mathrm{~J}=8.0 \mathrm{~Hz}, 2 \mathrm{H}), 7.25 \mathrm{~d}, \mathrm{~J}=$ $6.6 \mathrm{~Hz}, 2 \mathrm{H}), 7.15(\mathrm{~d}, \mathrm{~J}=5.6 \mathrm{~Hz}, 2 \mathrm{H}), 6.31(\mathrm{~d}, \mathrm{~J}=16.0 \mathrm{~Hz}$, $1 \mathrm{H}), 2.88(\mathrm{t}, \mathrm{J}=7.3 \mathrm{~Hz}, 2 \mathrm{H}), 2.56$ (quint, 2H); MS HR: $\mathrm{MH}^{+} m / z 278.1149$ (calcd for $\mathrm{C}_{16} \mathrm{H}_{15} \mathrm{NF}_{3}$ 278.1151), mp $78-79{ }^{\circ} \mathrm{C}$.

4-[4-(4-Methoxyphenyl)-but-1-enyl]-pyridine (free base of 1) was synthesized as follows. 3-(4-Methoxyphenyl)-propanol was prepared from 3-(4-methoxyphenyl)-propionic acid by Fisher esterification $(\mathrm{MeOH}$, $\mathrm{H}_{2} \mathrm{SO}_{4}$ ), followed by reduction with $\mathrm{LiAlH}_{4}$. All the next steps were performed according to the procedure described for 3. ${ }^{1} \mathrm{H}$ NMR $\left(\mathrm{CDCl}_{3}\right) \delta$ : trans-isomer: 8.47 $(\mathrm{d}, \mathrm{J}=5.1 \mathrm{~Hz}, 2 \mathrm{H}), 7.16(\mathrm{~d}, \mathrm{~J}=5.4 \mathrm{~Hz}, 2 \mathrm{H}), 7.10(\mathrm{~d}, \mathrm{~J}=$ $8.5 \mathrm{~Hz}, 2 \mathrm{H}), 6.62(\mathrm{~d}, \mathrm{~J}=8.3 \mathrm{~Hz}, 2 \mathrm{H}), 6.44(\mathrm{dt}, 1 \mathrm{H}), 6.30$ $(\mathrm{d}, \mathrm{J}=16.0 \mathrm{~Hz}, 1 \mathrm{H}), 3.78(\mathrm{~s}, 3 \mathrm{H}), 2.73(\mathrm{t}, \mathrm{J}=7.6 \mathrm{~Hz}, 2 \mathrm{H})$, 2.49 (quint, 2H) MS HR: $\mathrm{MH}^{+} \mathrm{m} / \mathrm{z} 240.1378$ (calcd for $\left.\mathrm{C}_{16} \mathrm{H}_{18} \mathrm{ON} 240.1383\right), \mathrm{mp} 84-86{ }^{\circ} \mathrm{C}$.

4-(4-Phenyl)-but-1-enyl)-pyridine (free base of 2) was prepared starting from commercially available 3-phenyl propanol-1 in the same manner as described for 3 . The free base of $\mathbf{2}$ was obtained as a mixture of isomers cis/trans 9:1 separated by column chromatography. ${ }^{1} \mathrm{H}$ $\operatorname{NMR}\left(\mathrm{CDCl}_{3}\right) \delta$ : cis-isomer-8.50 $(\mathrm{d}, \mathrm{J}=5.7 \mathrm{~Hz}, 2 \mathrm{H}), 7.21$ $(\mathrm{m}, 5 \mathrm{H}), 7.06(\mathrm{~d}, \mathrm{~J}=5.7 \mathrm{~Hz}, 2 \mathrm{H}), 6.34(\mathrm{~d}, \mathrm{~J}=11.7 \mathrm{~Hz})$, $5.87(\mathrm{dt}, \mathrm{J}=7.2 \mathrm{~Hz}, 6.6 \mathrm{~Hz}, 1 \mathrm{H}), 2.76(\mathrm{t}, \mathrm{J}=7.1 \mathrm{~Hz}, 2 \mathrm{H})$, 2.68 (quint, $2 \mathrm{H}$ ). MS HR: $\mathrm{MH}^{+} \mathrm{m} / \mathrm{z} 210.1278$ (calcd for $\left.\mathrm{C}_{15} \mathrm{H}_{16} \mathrm{~N} 210.1277\right), \mathrm{mp} 121-123{ }^{\circ} \mathrm{C}$.

4-[4-(4-Nitrophenyl)-but-1-enyl]-pyridine (free base of 6): 3-phenyl-propyl-1-bromide (prepared from commercially available 3-phenyl propanol-1 as described for 3) was nitrated [29, 30] with fuming nitric acid at -25 to $-30{ }^{\circ} \mathrm{C}$ for $0.5 \mathrm{~h}$ to afford a mixture of $o$ - and p-nitro products from which 3-(4-nitrophenyl)-propyl1-bromide was isolated by column chromatography in $46.8 \%$ yield. ${ }^{1} \mathrm{H} \mathrm{NMR}\left(\mathrm{CDCl}_{3}\right) \delta: 8.14(\mathrm{dd}, \mathrm{J}=6.8 \mathrm{~Hz}, \mathrm{~J}$ $=2.5 \mathrm{~Hz}, 2 \mathrm{H}), 7.35(\mathrm{~d}, \mathrm{~J}=8.5 \mathrm{~Hz}, 2 \mathrm{H}), 3.37(\mathrm{t}, 2 \mathrm{H}) 2.88$ $(t, 2 \mathrm{H}), 2.21$ (quint, $2 \mathrm{H})$. All the next steps for the transformation of 3-(4-nitrophenyl)-propyl-1-bromide to 6 were performed according to the procedures described for 3 .

${ }^{1} \mathrm{H}$ NMR $\left(\mathrm{CDCl}_{3}\right) \delta$ : cis isomer-8.52 $(\mathrm{d}, \mathrm{J}=6.2 \mathrm{~Hz}$, $2 \mathrm{H}), 8.11(\mathrm{~d}, \mathrm{~J}=8.7 \mathrm{~Hz}, 2 \mathrm{H}), 7.28(\mathrm{~d}, \mathrm{~J}=8.5 \mathrm{~Hz}, 2 \mathrm{H})$, $7.04(\mathrm{~d}, \mathrm{~J}=5.7 \mathrm{~Hz}, 2 \mathrm{H}), 6.37(\mathrm{~d}, \mathrm{~J}=11.8 \mathrm{~Hz}, 1 \mathrm{H}), 2.85$ (t, $\mathrm{J}=7.0 \mathrm{~Hz}, 2 \mathrm{H}$ ), 2.65 (quint, 2H). MS HR: $\mathrm{MH}^{+} \mathrm{m} / \mathrm{z}$ 255.1130 (calcd for $\mathrm{C}_{15} \mathrm{H}_{14} \mathrm{~N}_{2} \mathrm{O}_{2} 255.1128$ ).

4-(3-Cyclohepta-2,4,6-trienyl-propenyl)-pyridine (7) was prepared by Wittig reaction of cycloheptaprienylacetaldehyde with 4-picolylphosphonium bromide: $\mathrm{Cy}$ clohepta-2,4,6-trienylacetaldehyde was prepared from tropylium tetrafluoroborate and vinylethylether according to the literature procedure [31]. Yield 65\% after distillation on Kuhelrohr. ${ }^{1} \mathrm{H}$ NMR $\left(\mathrm{CDCl}_{3}\right) \delta$ : 9.76 $(\mathrm{t}, 1 \mathrm{H}), 6.64(\mathrm{t}, \mathrm{J}=3.0 \mathrm{~Hz}, 2 \mathrm{H}), 6.18(\mathrm{dd}, \mathrm{J}=9.0 \mathrm{~Hz}, \mathrm{~J}=$ $2.6 \mathrm{~Hz}, 2 \mathrm{H}), 5.16(\mathrm{dd}, \mathrm{J}=9.2 \mathrm{~Hz}, \mathrm{~J}=5.7 \mathrm{~Hz}, 2 \mathrm{H}), 2.77$ 
$(\mathrm{dd}, \mathrm{J}=6.7 \mathrm{~Hz}, \mathrm{~J}=1.4 \mathrm{~Hz}), 2.27(\mathrm{dd}, \mathrm{J}=6.7 \mathrm{~Hz}, \mathrm{~J}=1.4$ $\mathrm{Hz}, 2 \mathrm{H}), 2.27$ (quint, $1 \mathrm{H}$ ).

Compound 7 was prepared as follows: To $1.74 \mathrm{~g}, 4$ mmol of 4-picolyltriphenylphosphonium bromide in 15 $\mathrm{ml}$ dry $\mathrm{CH}_{2} \mathrm{Cl}_{2}$ under argon at room temperature was added dropwise $(0.40 \mathrm{~g}, 4 \mathrm{mmol}, 0.56 \mathrm{ml})$ of $\mathrm{Et}_{3} \mathrm{~N}$ in 2 $\mathrm{ml}$ of $\mathrm{CH}_{2} \mathrm{Cl}_{2}$. After $10 \mathrm{~min}$ stirring $(0.5 \mathrm{~g}$, $3.7 \mathrm{mmol})$ cyclohepta-2,4,6-trienylacetaldehyde in $2 \mathrm{ml}$ of $\mathrm{CH}_{2} \mathrm{Cl}_{2}$ were added and the reaction mixture was allowed to be stirrred for $24 \mathrm{~h}$. After usual aqueous workup, the crude product was isolated by column chromatography to give $7(0.7 \mathrm{~g}, 89 \%)$ as a mixture of cis- and trans-isomers. Yield $0.7 \mathrm{~g}, 89 \%$.

${ }^{1} \mathrm{H}$ NMR $\left(\mathrm{CDCl}_{3}\right)$ 8: cis/trans mixture $8.48(\mathrm{~d}, \mathrm{~J}=5.8$ $\mathrm{Hz}, 2 \mathrm{H}), 7.19(\mathrm{~d}, \mathrm{~J}=5.8 \mathrm{~Hz}, 2 \mathrm{H}), 6.64(\mathrm{t}, 2 \mathrm{H}), 6.48(\mathrm{~m}$, $2 \mathrm{H}), 6.18(\mathrm{~d}, \mathrm{~J}=9.0 \mathrm{~Hz}, 2 \mathrm{H}), 5.20(\mathrm{dd}, \mathrm{J}=9.0 \mathrm{~Hz}, \mathrm{~J}=5.5$ $\mathrm{Hz}, 2 \mathrm{H}), 2.64(\mathrm{dd}, \mathrm{J}=5.8 \mathrm{~Hz}, \mathrm{~J}=7.1 \mathrm{~Hz}, 2 \mathrm{H}), 1.81$ (quint, 1H). MS HR: $\mathrm{MH}^{+} \mathrm{m} / \mathrm{z} 210.1282$ (calcd for $\mathrm{C}_{15} \mathrm{H}_{16} \mathrm{~N}$ 210.1277).

4-(4-Phenyl-bytyl)-pyridine (19) was prepared by hydrogenation of $(0.086 \mathrm{~g}, 0.41 \mathrm{mmol})$ of the free base of 2 in $3 \mathrm{ml}$ of EtOH at $1 \mathrm{~atm}$ and room temperature, in the presence of $0.015 \mathrm{~g}$ of $5 \% \mathrm{Pd} / \mathrm{C}$ catalyst. After $24 \mathrm{~h}$ stirring the catalyst was filtered off, the resulting solution was concentrated in vacuum, affording a crystalline colorless product in $93 \%$ yield $(0.080 \mathrm{~g}) .{ }^{1} \mathrm{H}$ NMR $\left(\mathrm{CDCl}_{3}\right) \delta: 8.45(\mathrm{~d}, \mathrm{~J}=6.3 \mathrm{~Hz}, 2 \mathrm{H}), 7.22(\mathrm{~m}, 5 \mathrm{H}), 7.06(\mathrm{~d}$, $\mathrm{J}=5.7 \mathrm{~Hz}, 2 \mathrm{H}), 2.61(\mathrm{dt}, 4 \mathrm{H}), 1.63(\mathrm{~m}, 4 \mathrm{H})$. MS HR: $\mathrm{MH}^{+} \mathrm{m} / \mathrm{z} 212.1434$ (calcd for $\mathrm{C}_{15} \mathrm{H}_{18} \mathrm{~N}$ 212.1434), mp $44-46{ }^{\circ} \mathrm{C}$.

\section{Theoretical Methods}

All the calculations were carried out using Gaussian 98 package of programs [32]. All the molecules (unless indicated) under this study were optimized at the B3LYP/6-31G* hybrid density functional level of theory. For the study of each process, a potential energy surface scan was employed, and the starting materials, products and transition states were analyzed using analytical frequencies calculations.

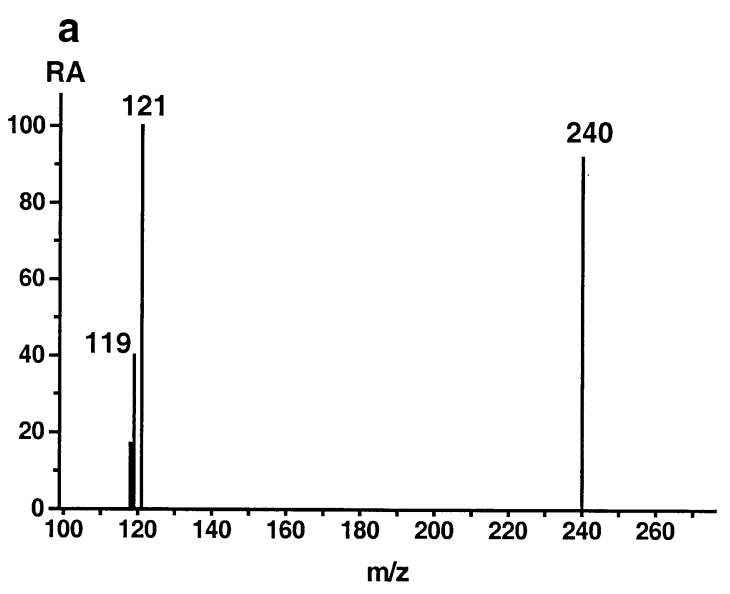

\section{Results and Discussion}

\section{Mass Spectrometry}

Pyridinium cations $\mathbf{1}$ and $\mathbf{1 a}$ are readily produced, in the gas phase, from the corresponding halide salts, using fast atom bombardment (in glycerol) or electrospray ionization (in $\mathrm{CH}_{3} \mathrm{CN} / \mathrm{MeOH}$ ). This system contains a well defined charged site remote from the expected fragmentation site, in this case a benzylic $\mathrm{C}-\mathrm{C}$ bond, but nevertheless associated by conjugation.

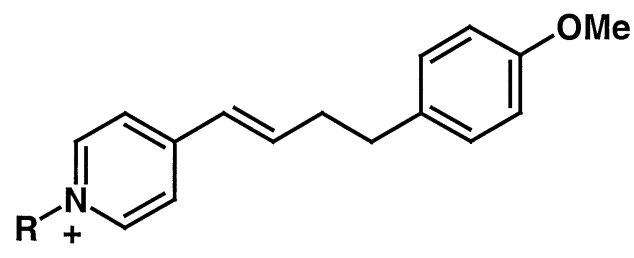

\section{1- $\mathbf{R}=\mathbf{H}, \mathbf{1 a}-\mathbf{R}=\mathrm{Me}$}

CID spectra that were recorded for FAB-produced 1 and 1a are shown in Figure 1. They exhibit two major product ions that correspond to the two fragmentation pathways described in Scheme $2\left(\mathrm{X}=\mathrm{OCH}_{3}\right)$, namely the homolytic and heterolytic cleavages at the benzylic position. The products of the homolytic cleavage are a radical cation and a benzyl radical (route a), whereas the products of the heterolytic cleavage are a neutral amine and a benzyl cation (route b). Unpredictably, the protonated ion 1 dissociated to afford mostly the $p$ methoxy benzyl cation (Figure 1a, RA, 100\%) while the methylated analog 1a gives rise to a prominent radical cation at $\mathrm{m} / \mathrm{z} 133$ (Figure 1b, RA 65\%).

The ion ratio in the CID spectra depends on the nature of the substituent $X$ at the phenyl ring (Scheme 2). Thus pyridinium ions $2, \mathbf{4}, \mathbf{5}$ and $\mathbf{6}$ all dissociate in a homolytic manner exclusively (Figure 2, Table 1), 1 and 3 give rise to a mixture of products and 7 affords only a closed-shell product (Scheme 3). Pyridinium ions 1-6

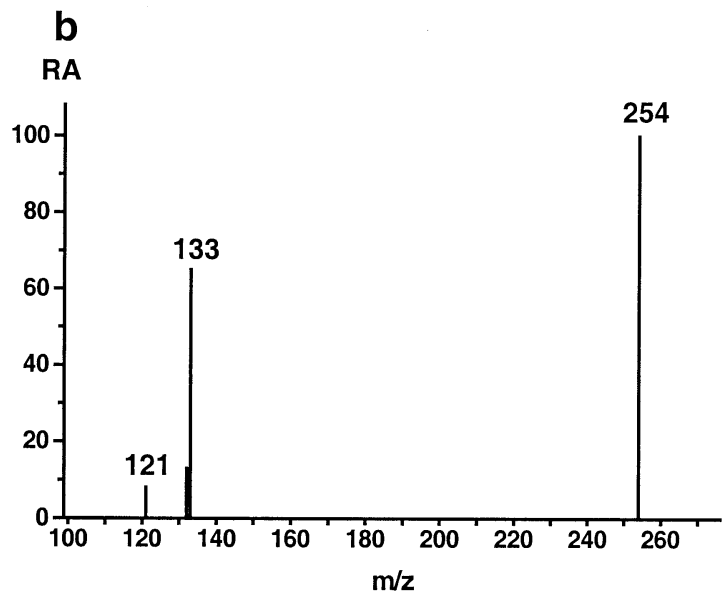

Figure 1. (a) CID spectrum of FAB produced protonated cation 1. (b) CID spectrum of FAB produced methylated cation 1a. Argon was used as collision gas, collision offset $=10 \mathrm{eV}$. 


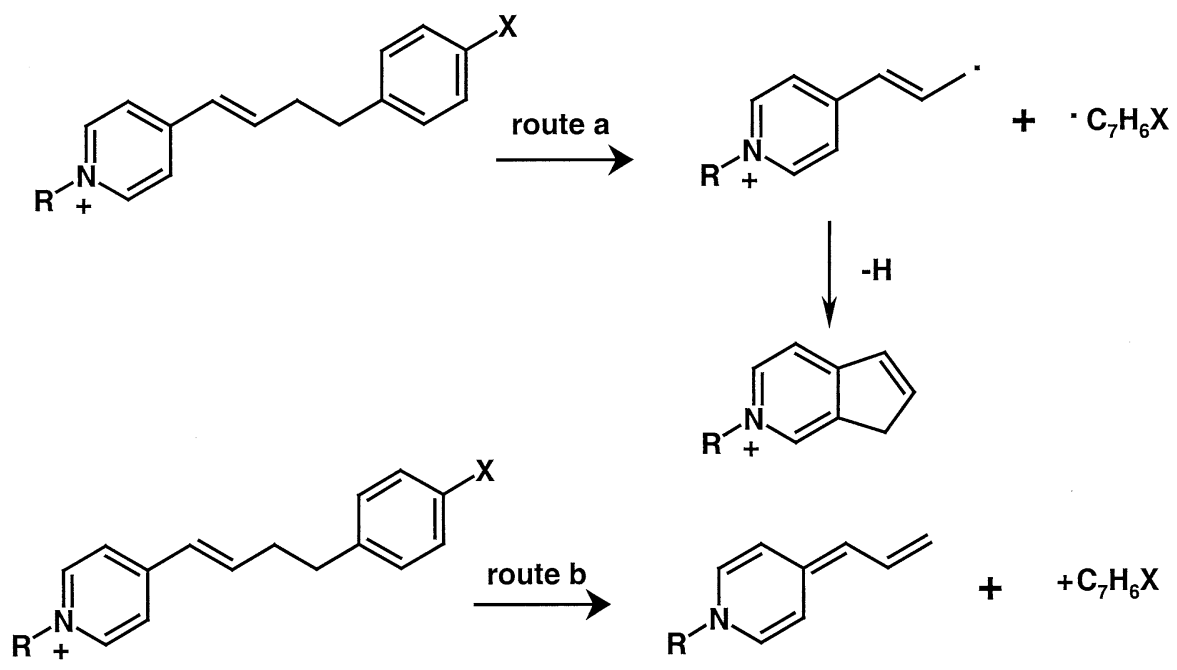

Scheme 2. Two competitive fragmentation pathways: Homolytic and heterolytic, leading to the formation of radicals and closed shell ions, respectively.

are generated from the free bases that are synthesized as cis/trans mixtures. The two isomers were separated and it was found that while the two isomers afford the same fragmentation products, the trans isomer is slightly more reactive.
The benzylic $\mathrm{C}-\mathrm{C}$ cleavage is motivated by either collisions with argon, IR irradiation or merely slightly amplified capillary voltage at the electrospray source, indicating the low energy involved in this process. Higher energy allows the consecutive loss of a hydro-<smiles>[X]c1ccc(CCC=CC2=CC=[NH+][CH+]2)cc1</smiles><smiles>C[n+]1ccc(/C=C/CCc2ccccc2)cc1</smiles>

$2-\mathrm{X}=\mathrm{H} ; 3-\mathrm{X}=\mathrm{CH}_{3}, 4-\mathrm{X}=\mathrm{Cl}, 5-\mathrm{X}=\mathrm{CF}_{3}, 6-\mathrm{X}=\mathrm{NO}_{2}$

$2 a$

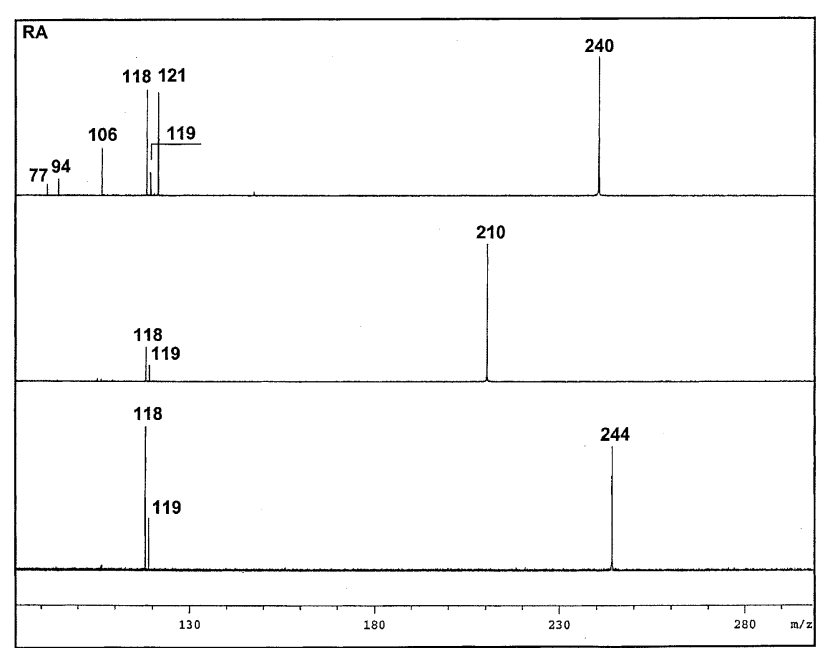

Figure 2. CID spectra that were recorded for electrospray produced, protonated pyridinium cations. Upper spectrum corresponds to 4-methoxy substituted $\mathbf{1}$, middle spectrum corresponds to non substituted 2, and the lower spectrum corresponds to 4-chloro substituted 4 . gen atom and the formation of a cyclized closed-shell product (Scheme 2) [12]. Pyridinium cations 2-7 can be divided into three groups. For the first group cationic reactions dominate either through the formation of a benzylic cation $\mathrm{ArCH}_{2}^{+}$(1), protonated 4-vinylpyridine, at $m / z 106$ (1 and 3, Scheme 3) or tropylium cation in the case of 7 . The second group contains substituents that enhance homolytic cleavage and form the ions at $\mathrm{m} / \mathrm{z}$ 119 and 118 in high yield. This group includes cations 4 and 5 that contain trifluoromethyl and chloro substituents respectively. The third group, namely pyridinium

Table 1. Relative abundances of ions in the CID spectra recorded for electrospray produced substituted pyridinium cations 1-6

\begin{tabular}{rcccccc}
\hline & $\mathrm{X}$ & $\begin{array}{c}\text { Parent } \\
\text { ion }\end{array}$ & $\begin{array}{c}\mathrm{m} / \mathrm{z} \\
\mathrm{m} / \mathrm{z}\end{array}$ & $\begin{array}{c}118 \\
\mathrm{~m} / \mathrm{z}\end{array}$ & \multicolumn{1}{c}{$\mathrm{ArCH}_{2+}$} \\
\hline \hline 1 & $\mathrm{OMe}$ & 100 & 17 & 77 & 34 & 74 \\
2 & $\mathrm{H}$ & 100 & 10 & 25 & - & - \\
3 & $\mathrm{Me}$ & 100 & 13 & 56 & 12 & - \\
4 & $\mathrm{Cl}$ & 85 & 23 & 100 & - & - \\
5 & $\mathrm{CF}_{3}$ & 100 & 20 & 40 & - & - \\
6 & $\mathrm{NO}_{2}$ & 100 & 7 & 17 & - & - \\
\hline
\end{tabular}




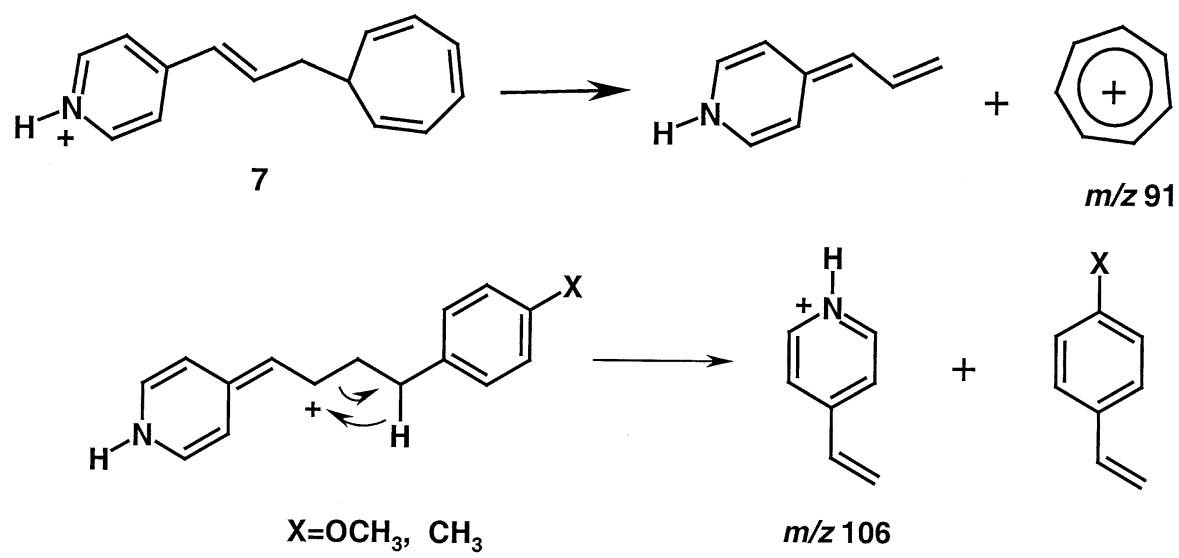

Scheme 3. Proposed fragmentation mechanism yielding the closed shell products in the CID spectra of 7,1 , and 3 .

cations 2 and 6 have a low tendency do dissociate through either of the mechanisms, however if the energy is increased they undergo homolytic cleavage.

Thermochemical data for the reactions described in Scheme $\mathbf{1}$ have been calculated for protonated $\mathbf{2}$ and methylated 2a using density functional theory at the B3LYP/6-31G* level. The results of these calculations show that the homolytic cleavage (route a) in methyl pyridinium ion $2 \mathrm{a}$ requires $50.1 \mathrm{kcal} \mathrm{mol}^{-1}$ (including ZPE correction), whereas the competitive heterolytic cleavage (route b) corresponds to a $\Delta \mathrm{E}$ of $78.5 \mathrm{kcal}$ $\mathrm{mol}^{-1}$. In the case of 2 the homolytic cleavage (route a) requires $50.1 \mathrm{kcal} \mathrm{mol}^{-1}$ (including ZPE correction), whereas the competitive heterolytic cleavage (route b) corresponds to a $\Delta \mathrm{E}$ of $74.7 \mathrm{kcal} \mathrm{mol}^{-1}$. The calculated $\Delta \mathrm{E}$ values are relatively high although the energetic conditions can explain the occurrence of these reactions. The amount of energy that is introduced to the ion upon collision is not known. Heeren and Vékey showed that in an individual collision with argon $9.6 \%$ of the center of mass collision energy is converted into internal energy [33]. The reactions above occur upon collision with Ar and the center of mass collision energy is roughly $1.4 \mathrm{eV}$. This should correspond to roughly 3 $\mathrm{kcal} \mathrm{mol}^{-1}$ for a single collision. It is difficult to evaluate the agreement between the experimental results and theoretical calculations because the temperature in the collision cell is not well defined and the free energy cannot be derived from internal energy. In order to have a better estimation about the accuracy of this calculation it should be repeated at higher theoretical level. However, it was not possible to improve the calculations for such a large system. Alternatively, a smaller model was chosen in order to study the effect of calculation method on the calculated reaction energy. Table 2 contains the calculated thermochemical data for this model reaction that is described in Scheme 4 . The energy values alone have little meaning as they were calculated for a model. It is only the direction and degree of change that we are interested in. Table 2 shows that the expansion of the basis set while using
B3LYP results in a slight reduction in reaction energy for both homolytic and heterolytic cleavages. However, the preference of the homolytic process over the heterolytic path decreases significantly. This correlates well with our finding that the difference is small and the course of fragmentation can be controlled by changing the substituent at the para position. Contrarily, MP2 and MP4 energies are significantly higher. These calculated results also predict that heterolytic cleavages should be favored in this system and are therefore clearly less suited than the DFT method. [Table 2 shows that higher-level calculations could resolve the discrepancy between the theoretical prediction of highly endothermic reactions and the observed experimental products. However, we were not able to improve the calculations on the true model.]

The calculated energies for the decomposition reactions of both ions 2 and $2 \mathbf{a}$ indicate a preference towards the homolytic pathway. Nevertheless, the experimental results show a significant difference between the CID spectra of $\mathbf{1}$ and 1a. Possibly, the different behavior of $\mathbf{1}$ (compared with 1a) is due to a rearrangement that requires a proton at the nitrogen atom. This could also indicate that the product ion corresponds to a rearranged structure. However, the ion 1 at $\mathrm{m} / \mathrm{z} 240$ and the

Table 2. Calculated homolytic and heterolytic dissociation energies (see Scheme 4, $\mathrm{X}=\mathrm{H}$ ), in $\mathrm{kcal} \mathrm{mol}^{-1}$. Energies are given with ZPE correction except for structures that were calculated using MP4/6-311G**//MP2/6-311G* for which ZPE was not calculated

\begin{tabular}{lccc}
\hline Method & $\Delta$ Eho & $\Delta$ Ehe & \multicolumn{1}{c}{$\Delta$} \\
\hline \hline B3LYP/6-31G*//B3LYP/6-31G* & 59.6 & 65.3 & 5.7 \\
B3LYP/6-311G*//B3LYP/6-311G* & 58.6 & 63.3 & 4.7 \\
B3LYP/6-311G**B3LYP/6-311G** & 57.5 & 61.9 & 4.4 \\
B3LYP/6-211+G**//B3LYP/6-311+G** & 56.8 & 59.4 & 2.6 \\
B3LYP/6-311++G**//B3LYP/6/311++G** & 56.8 & 59.4 & 2.6 \\
B3LYP/D95V+*//B3LYP/D95V+* & 58.4 & 62.0 & 3.6 \\
MP2/6-31G*//MP2/6-31G* & 78.3 & 72.4 & -5.9 \\
MP2/6-31G**//MP2/6-311G* & 78.8 & 72.0 & -6.8 \\
MP4/6-311G**//MP2/6-31G* & 77.5 & 74.9 & -2.6 \\
\hline
\end{tabular}




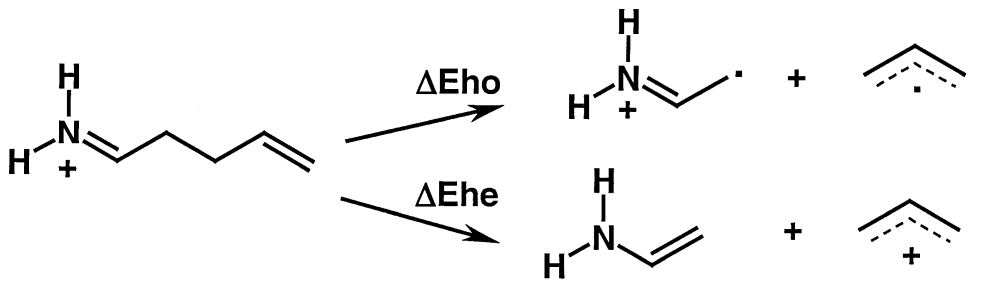

Scheme 4. The homolytic and heterolytic reactions that were studied theoretically. Results are presented in Table 2.

analog deuterated ion at $\mathrm{m} / \mathrm{z} 241$ (electrospray-produced in $\mathrm{CD}_{3} \mathrm{OD}$ ) show similar behavior upon $\mathrm{CID}$ (not shown). In order to understand this distinct behavior and compose a reaction mechanism for this process, the potential energy surface was explored. For this study model systems $\mathbf{8}$ and $\mathbf{8 a}$ were used.

The dissociation pathways of $\mathbf{8}$ and $\mathbf{8 a}$ were characterized by stepwise increasing the length of the breaking bond, while optimizing all other coordinates at each given bond length. For a typical reaction it is possible to refine the transition state geometry from the points with the highest energy along the path. Figure 3 illustrates the calculated singlet and triplet potential energy curves for an allylic C-C cleavage in 8 using ORB3LYP and UB3LYP methods. The energy along the singlet potential energy surface increases monotonously with the $\mathrm{C}-\mathrm{C}$ elongation. It is, in fact impossible to locate a transition state along the reaction coordinates.

The charge distribution within the dissociating transient structures was also calculated using natural bond orbital analysis (NBO). These calculations indicate that

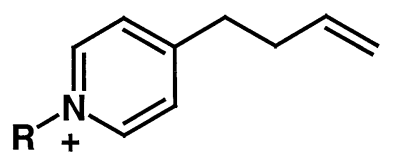

\section{$8-\mathrm{R}=\mathrm{H} \quad 8 \mathbf{a}-\mathrm{R}=\mathrm{Me}$}

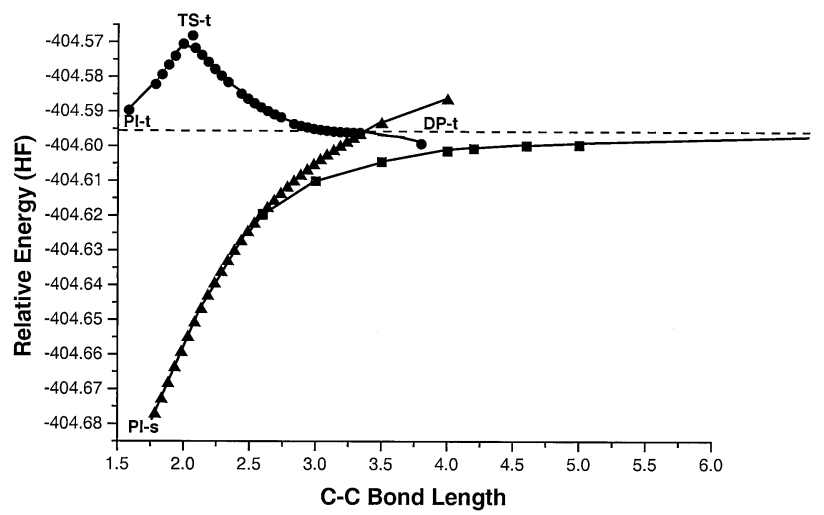

Figure 3. Calculated triplet (circles) and singlet (triangles), calculated potential energy curves for the dissociation of model compound 8 . The additional curve, designated by squares, corresponds to mixed states that are neither triplet nor singlet states. Calculations were carried out at the B3LYP/6-31G* DFT level of theory. along the singlet curve positive charge is accumulated at the terminal propenyl moiety.

On the other hand the triplet potential energy surface comprises a well characterized starting material, a transition state and a final product (Figure 3), (Table 3). A full geometry optimization and frequencies analysis were performed for the reactant and product of the dissociation reactions. PI-s in Figure 4 is the initial structure (parent ion) of the singlet protonated pyridine 8. The allylic $\mathrm{C}-\mathrm{C}$ bond length in this structure is 1.539 $\AA$ and the double bond is planar. PI-s corresponds to the lowest energy in the potential energy curve. PI-t is the initial structure (parent ion) of the triplet protonated pyridine 8 . The allylic $\mathrm{C}-\mathrm{C}$ bond length in this structure is $1.584 \AA$ while the double bond is perpendicular. Calculations show that PI-t is $61.4 \mathrm{kcal} \mathrm{mol}^{-1}$ less stable than PI-s. PI-t dissociates into an ion-neutral complex DP-t (dissociation product) through a $13.5 \mathrm{kcal} \mathrm{mol}^{-1}$ barrier (TS-t). DP-t is $55.3 \mathrm{kcal} \mathrm{mol}^{-1}$ less stable than the starting structure PI-s. However, the separated dissociation products are roughly $46 \mathrm{kcal} \mathrm{mol}^{-1}$ less stable than this ion-neutral complex DP-t.

The calculated results show that a vertical singlettriplet transition is highly endoergic (Figure 3 ) and not likely to occur within the initial geometry of $\mathbf{8}$ or $\mathbf{8 a}$. Nevertheless, along with the $\mathrm{C}-\mathrm{C}$ bond elongation the vertical singlet-triplet transition decreases. Furthermore

Table 3. Calculated charge and spin distribution as a function of bond length in dissociating transient structures of pyridinium cation 8a

\begin{tabular}{cccc}
\hline & $\begin{array}{c}\text { singlet path- } \\
\text { charge at the } \\
\text { propenyl moiety }\end{array}$ & $\begin{array}{c}\text { triplet path- } \\
\text { charge at the } \\
\text { propenyl moiety }\end{array}$ & $\begin{array}{c}\text { triplet path-spin } \\
\text { at the propenyl } \\
\text { moiety }\end{array}$ \\
\hline \hline $1 . \AA 255$ & 0.614 & 0.853 & 0.395 \\
1.685 & 0.634 & 0.891 & 0.395 \\
1.735 & 0.646 & 0.905 & 0.541 \\
2.185 & 0.770 & 0.724 & 0.968 \\
2.585 & 0.854 & 0.581 & 0.972 \\
2.785 & 0.877 & 0.546 & 0.946 \\
\hline
\end{tabular}

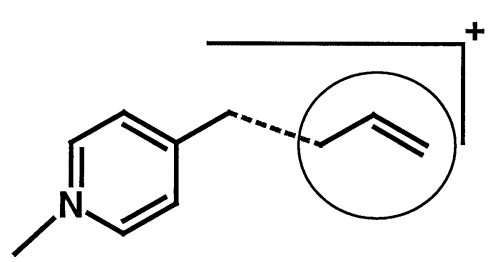




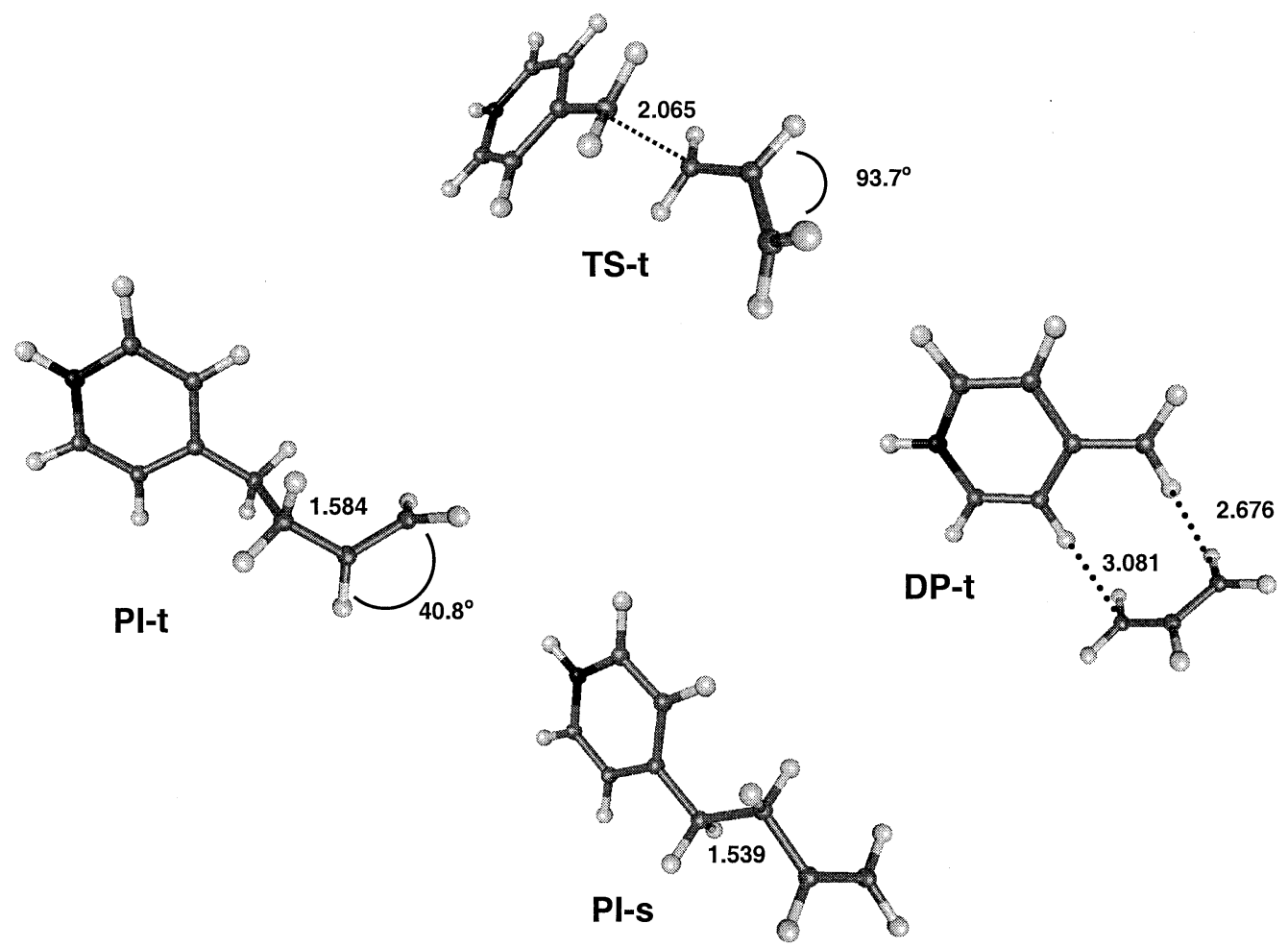

Figure 4. Description of the maxima and minima along the potential energy curve presented in Figure 3. PI-s is the singlet dissociating parent ion at the initial point, PI-t is the corresponding triplet structure, TS-t is the transition state that was located along the triplet potential energy curve, and DP-t is the dissociation product at the triplet potential energy curve.

the calculated potential energy curve of the singlet state and the triplet state cross at a certain point that corresponds to a C-C bond of $3.5 \AA$ (Figure 3 ). The highly efficient homolytic cleavage and the theoretical calculations suggest a change in multiplicity along with the $\mathrm{C}-\mathrm{C}$ bond cleavage. When the reaction path was calculated allowing the mixing of the HOMO and LUMO states a different potential curve that corresponds to lower energy emerges but the resulting transient points show high spin contamination. In fact, $<\mathrm{s}^{2}>$ gradually increased with the $\mathrm{C}-\mathrm{C}$ bond length. If the singlettriplet vertical transition is an indication for this mixing it is clear that this value decreases with the increase in $\mathrm{C}-\mathrm{C}$ bond length (Figure 5). Apparently, the singlettriplet vertical transition is higher in the case of protonated cation $\mathbf{8}$ when compared with the alkylated cation 8a. This could explain the preference of homolytic cleavage in the methylated cation.

\section{Substituents and Radical Stability}

The experimental results shown in Figure 2 and Table 1 demonstrate that an electron donating group, e.g., methoxy, stabilizes the benzyl cation and permits the formation of closed-shell products. Some substituents can stabilize both cations and radicals. Table 4 summarizes the calculated energy for hydrogen transfer (HT) in comparison with proton transfer (PT) reactions. DFT calculations indicate that the substituent effect on the competition between the formation of radicals or cations in the case of $\mathbf{9 - 1 2}$ is mainly directed by the relative stability of the cations and not the corresponding radicals (Scheme 5), (Table 4).

As the findings of this study point to the involvement of a triplet electronic state, the sum effect of substituents could also result by reduction in the S-T splitting. Table 5 summarizes the results of DFT calcu-

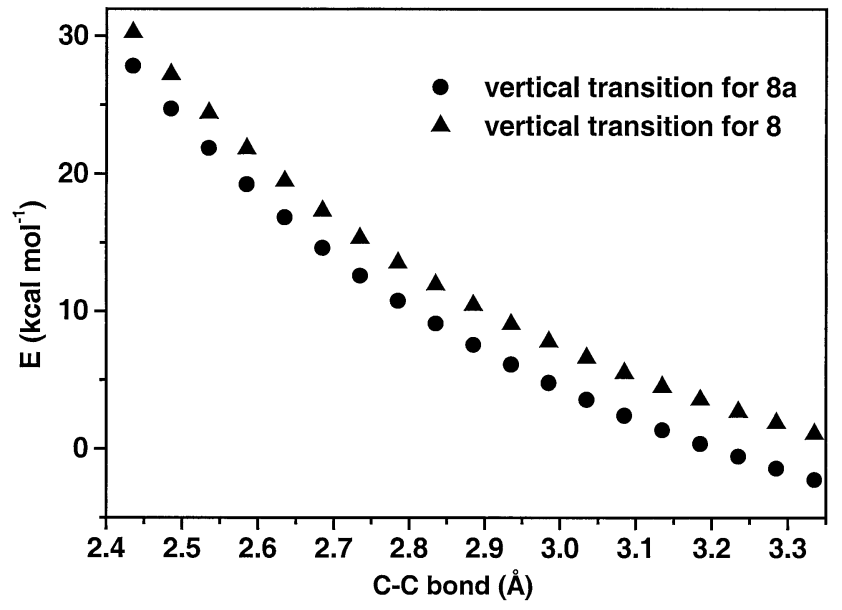

Figure 5. Calculated vertical singlet-triplet transition energies as a function of $\mathrm{C}-\mathrm{C}$ bond length in the model compounds $\mathbf{8}$ and $\mathbf{8 a}$. The singlet-triplet transition decreases at longer $\mathrm{C}-\mathrm{C}$ bonds and is less energetic for methylated $\mathbf{8 a}$ than for protonated $\mathbf{8}$. 
Table 4. Calculated ( $\Delta \mathrm{E}$ with ZPE correction, in $\mathrm{kcal} \mathrm{mol}^{-1}$ ) hydrogen and proton transfer in substituted benzyl cations and radicals (see Scheme 5). $\mathrm{E}(\mathrm{HT})$ and $\mathrm{E}(\mathrm{PT})$ are the hydrogen and proton transfer from the a non-substituted toluene. $\mathrm{E}(\mathrm{PT}-\mathrm{HT})$ are the differences between these values, an indication of the preference for cation formation over radical formation in each molecule

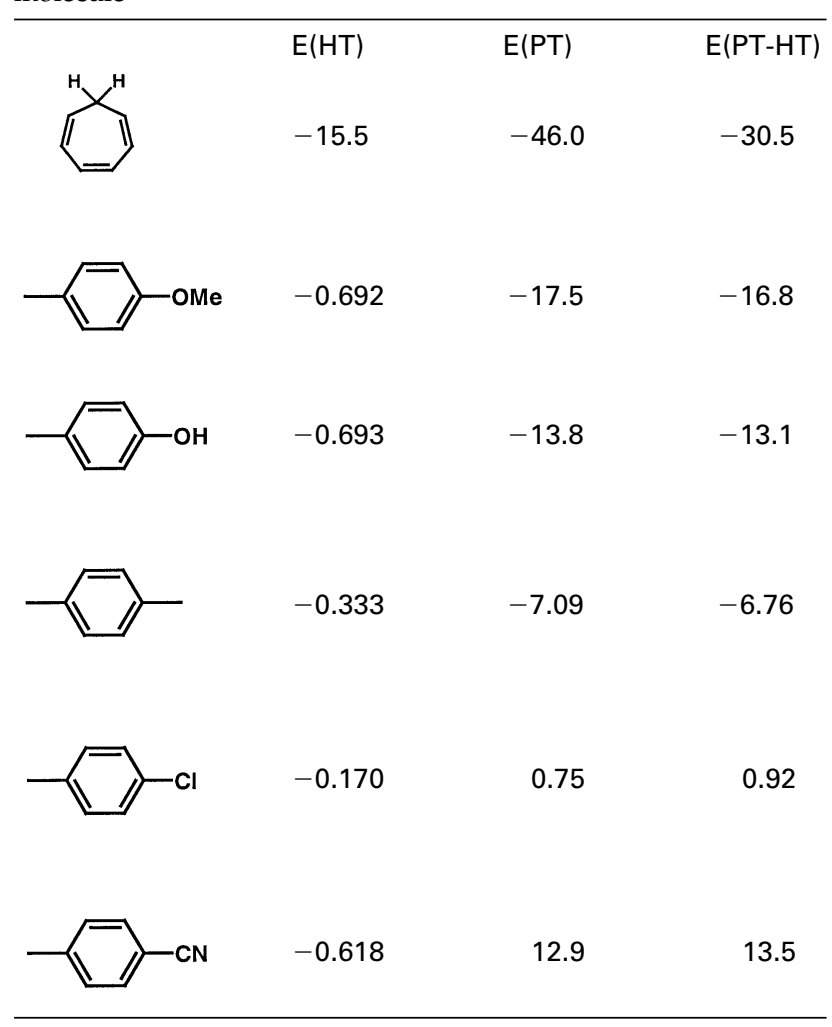

lations (B3LYP / 6-31G*) for the vertical S-T transition in model compounds 9-12. The calculated results show a clear substituent effect on the singlet-triplet vertical transitions. It appears that an electron donating substituent (i.e., $\mathrm{OH}$ ) causes a decrease in the vertical S-T transition in the optimized structures with typical $\mathrm{C}-\mathrm{C}$ bond length. However, in the transient structures for which the benzylic C-C bond is elongated ( $2.5 \AA)$ the substituent effect on the vertical transition is reversed
Table 5. Substituent effect on the singlet-triplet vertical transition at optimized $\mathrm{C}-\mathrm{C}$ bond length and a stretched $\mathrm{C}-\mathrm{C}$ bond of $2.5 \AA$. Energies in kcal $\mathrm{mol}^{-1}$

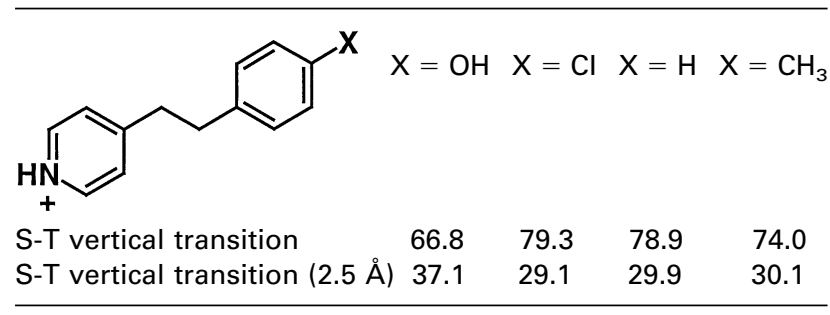

and the electron withdrawing substituent (i.e., $\mathrm{Cl}$ ) decreases the S-T transition. This is in agreement with the experimental findings that show the high tendency of 4 that contains a chlorine at the para positions to afford radicals while undergoing a benzylic $\mathrm{C}-\mathrm{C}$ cleavage.

\section{Triphenyl Phosphonium Cations}

The systems presented above contain a conjugated spacer so that the presence of charge at the homobenzylic position is expected. Contrarily, triphenyl phosphonium cations 13-18 contain a localized charge that is not directly conjugated to the substituted benzyl moieties. The CID spectra of these ions (Figure 6, Table 6) contain several types of ions.

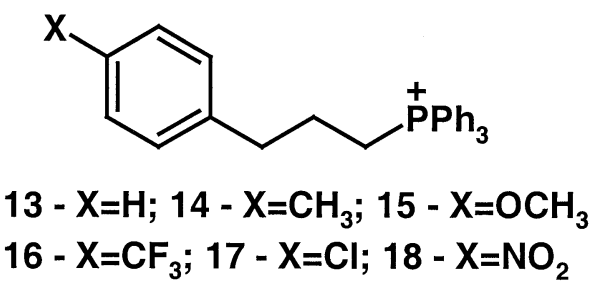

Benzyl cations are generated in the case of $\mathbf{1 3}(X=\mathrm{H}$, $m / z$ 91) and $14\left(\mathrm{X}=\mathrm{CH}_{3}, \mathrm{~m} / \mathrm{z}\right.$ 105) by the corresponding heterolytic cleavages. The relative abundance of these ions in the IRMPD spectrum of $\mathbf{1 3}$ and $\mathbf{1 4}$ is roughly $15 \%$. A most abundant product ion present in the

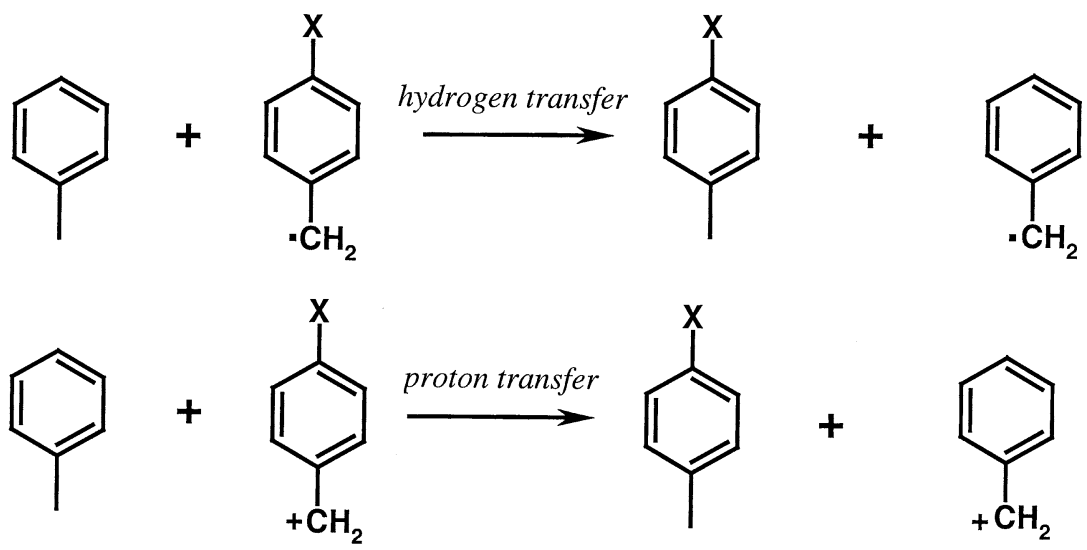

Scheme 5. Hydrogen and proton transfer reactions that were studied theoretically at B3LYP/6-31G*. Results are presented in Table 4. 


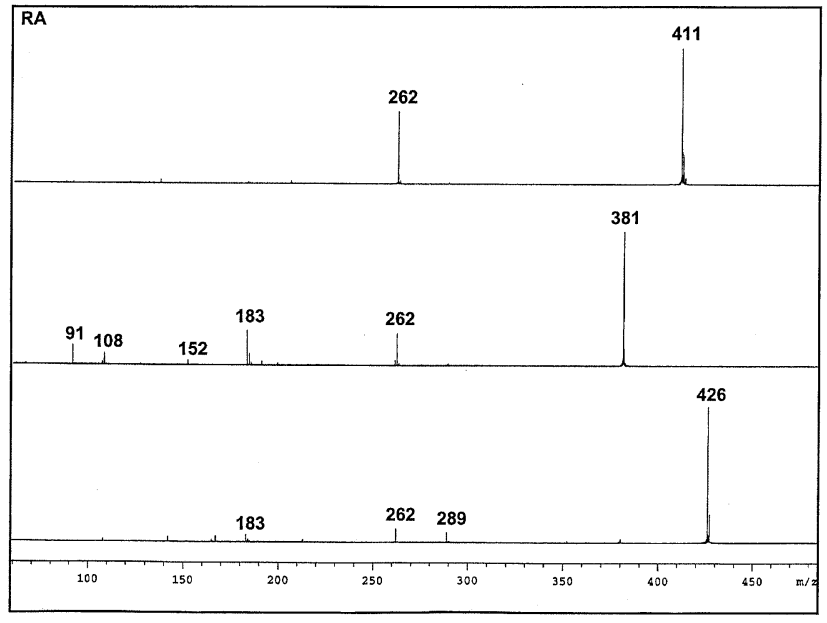

Figure 6. CID spectra that were recorded for electrospray produced, protonated triphenylphosphonium cations. Upper spectrum of 4-methoxy substituted 15, middle spectrum of non substituted 13, and the lower spectrum of 4-nitro substituted 18.

spectra of phosphonium cations $\mathbf{1 3 - 1 8}$ is a triphenyl phosphine radical cation at $m / z 262$. This ion can further decompose to form the $o$-biphenylenephosphenium ion at $m / z 183$ [34] that can lose a phosphorous atom and form the ion at $\mathrm{m} / \mathrm{z} 152$. The ion at $\mathrm{m} / \mathrm{z} 262$ can also lose two phenyl groups and thus form the product ion at $\mathrm{m} / \mathrm{z}$ 108. Another course of fragmentation is most favored in the case of phosphonium cation $18\left(X=\mathrm{NO}_{2}\right)$ and involves the formation of an ion at $\mathrm{m} / \mathrm{z} 289$ that is described in Scheme 6. The RA of the triphenyl phosphine radical cation in the CID spectra of 12-18 depends on the substituent $X$ at the phenyl ring despite the lack of conjugation between the charge and the benzyl group. Scheme 6 describes a possible mechanism for the formation of these ions. Figure 6 and Table 6 show that cations $\mathbf{1 3}$ and $\mathbf{1 4}$ undergo both heterolytic and homolytic cleavages. Surprisingly, the 4-methoxy substituted cation $\mathbf{1 3}$ undergoes only a homolytic cleavage under low energy conditions, affording ionized triphenyl phosphine that does not further decompose. Even more surprising is that the 4-chloro substituted $\mathbf{1 7}$ is considerably more stable and does not fragment at all under these conditions, while the analogous pyridinium cation 4 showed relatively high reactivity. Possibly there are at least two mechanisms operative and the chloro substituted $\mathbf{1 7}$ is not reactive in any one of them [35]. [In accordance with the referee's remark it is noted that the interaction between the positive phos- phorous atom and the electron-rich aromatic ring might initiate the observed fragmentations. However the high abundance of the triphenylphosphine cation $(\mathrm{m} / \mathrm{z} 262)$ in the spectra indicates that this is not a major course of reaction. Also noted that Fast atom bombardment experiments on alkyltriphenylphosphonium cations also indicate that the loss of alkyl groups as the most facile reaction.]

The extent of benzylic $\mathrm{C}-\mathrm{C}$ cleavage either homolytic or heterolytic is higher in the case of pyridinium cations 1-7 when compared with the posphonium cations 13-18 in which the charge is not conjugated to the benzylic position. Pyridinium cation 19 in which the charge and phenyl group are also tethered by a saturated butyl moiety is also very stable towards collisional activation. Higher collision energy induces $\mathrm{C}-\mathrm{C}$ cleavage alpha to the pyridine, giving rise to a low abundant ion at $\mathrm{m} / \mathrm{z} 93$ (RA $10 \%$, at the same energy used for CID experiments in the case of 1-7).<smiles>c1ccc(CCCCc2cc[nH+]cc2)cc1</smiles>

\section{Conclusions}

Homolytic cleavages are highly efficient in the case of the pyridinium cations that were studied in this work. We find that the tendency to form radicals is higher for alkylated pyridinium cation that contains a $p$-methoxy benzyl group than in the case of the protonated analog 1 that affords closed-shell products. Theoretical calculations show that the singlet pyridinium ions are much more stable than the corresponding triplets. However, the singlet-triplet gap for transient structures with an elongated benzylic $\mathrm{C}-\mathrm{C}$ bond is much lower and even changes sign. It is therefore suggested that the mixing of these states allows the relatively low energy $\mathrm{C}-\mathrm{C}$ homolytic cleavage. Calculations also show that the singlet-triplet gap is lower for the alkylated pyridinium cation than the protonated one, both used as model compounds for this study. This could explain the higher tendency of alkylated ions to dissociate to afford radicals. There is an apparent substituent effect in the CID spectra of pyridinium cations 1-7. Thus formation of

Table 6. Relative abundances of ions in the CID spectra recorded for substituted triphenylphosphonium cations 13-18

\begin{tabular}{|c|c|c|c|c|c|c|c|}
\hline & $x$ & Parent ion & $m / z 262$ & $\mathrm{~m} / \mathrm{z} 183$ & $\mathrm{~m} / \mathrm{z} 108$ & $m / z 289$ & $\mathrm{ArCH}_{2+}$ \\
\hline 13 & $\mathrm{H}$ & 100 & 23 & 24 & 9.5 & - & 12 \\
\hline 14 & $\mathrm{Me}$ & 100 & 19 & 5 & - & 2 & 12 \\
\hline 15 & OMe & 100 & 55 & - & - & - & - \\
\hline 16 & CF3 & 100 & 13 & 2 & - & - & - \\
\hline 17 & $\mathrm{Cl}$ & 100 & - & - & - & - & - \\
\hline 18 & $\mathrm{NO}_{2}$ & 100 & 10 & 5.5 & 2.5 & 7.5 & - \\
\hline
\end{tabular}



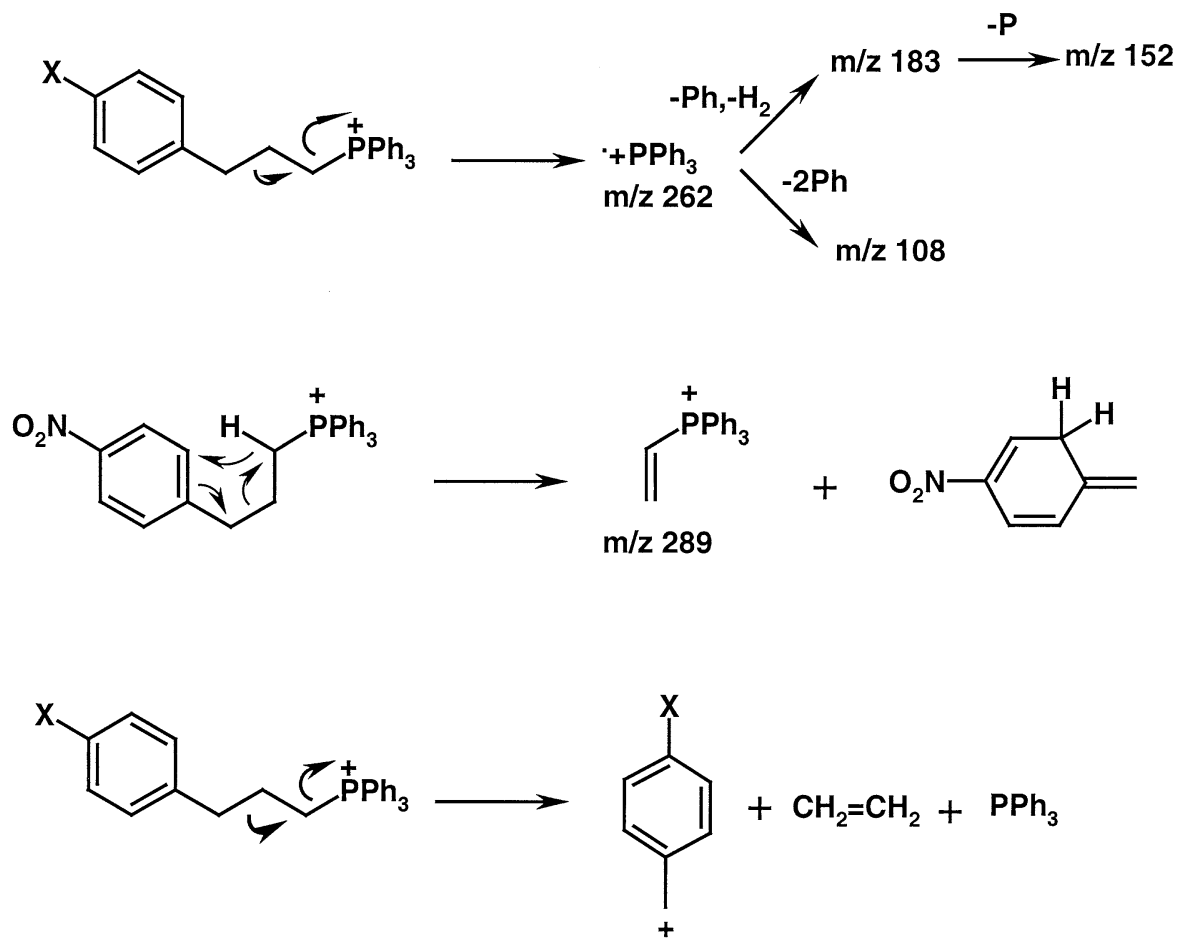

\section{$\mathrm{X}=\mathrm{H}, \mathrm{Me}$}

Scheme 6. Proposed fragmentation mechanisms yielding the product ions observed in the CID spectra that were recorded for triphenylphosphonium cations 13-18.

radicals is much favored when para electron withdrawing groups are present at the phenyl ring and exclusive heterolytic cleavage is observed in the case of 7 that gives rise to a tropylium cation upon CID. In addition to the notable substituent effect on the fragmentation efficiency of the cations under study, calculated results show a clear substituent effect on the singlet-triplet transitions. We also observe that the substituent effect in the case of triphenylphosphonium cations is notably different. Thus, the pyridinium system that contains a $p$-chloro benzyl moiety losses a benzyl radical readily while the analogous triphenylphosphonium cation is very stable under the same conditions.

\section{Acknowledgments}

This research was supported by the Israel Science Foundation and the by the fund for promotion of research at the Technion and by the Technion VPR.

\section{References}

1. Cheng, C. Gross M. L. Applications and Mechanisms of Charge-Remote Fragmentation. Mass Spectrom. Rev. 2000, 19, 398-420, and references cited therein.

2. Gross, M. L. Charge-Remote Fragmentation: An Account of Research on Mechanisms and Applications. Int. J. Mass Spectrom. 2000, 200, 611-624, and references cited therein.

3. Tuinman, A. A.; Cook, K. D.; Magid, L. J. Charge-Remote Fragmentation in a Hybrid (BEqQ) Mass Spectrometer to Determine Isotopic Purity in Selectively Polydeuterated Surfactants. J. Am. Soc. Mass Spectrom. 1990, 1, 85-91.
4. Whalen, K.; Grossert, J. S.; Curtis, J. M.; Boyd, R. K. Mixed-Site versus Charge-Site-Remote Fragmentation Reactions of LongChain Quaternary Ammonium Ions. Int. J. Mass Spectrom. Ion Processes 1997, 160, 223-240.

5. Seto, C.; Grossert, J. S.; Waddel, D. S.; Curtis, J. M.; Boyd, R. K. Studies of Mixed-Site and Charge-Site-Remote Fragmentations of Quaternary Ammonium Ions. II. Effects of Chain Length. Int. J. Mass Spectrom. 1999, 188, 27-38.

6. Wysocki, V. H.; Ross, M. M. Charge-Remote Fragmentation of Gas-Phase Ions: Mechanistic and Energetic Considerations in the Dissociation of Long-Chain Functionalized Alkanes and Alkenes. Int. J. Mass Spectrom. Ion Processes 1991, 104, 179-211.

7. Claeys, M.; Nizigiyimana, L. Van Den; Heuvel, H.; Vedernikova, I.; Haemers, A. Charge-Remote and Charge-Proximate Fragmentation Processes in Alkali-Cationized Fatty Acid Esters upon High-Energy Collisional Activation. A New Mechanistic Proposal. J. Mass Spectrom. 1998, 33, 631-643.

8. Denekamp, C.; Pocsfalvi, G.; Claeys, M. Charge-Remote and Charge-Proximate Fragmentations in Deuterium-Labeled$n$-Hexadecyltriphenylphosphonium Cations Upon High-Energy Collisional Activation: Evidence for the Involvement of Phenyl biradicals. Int. J. Mass Spectrom. 1999, 188(3), 163-175.

9. Voinov, V. G.; Van den Heuvel, H.; Claeys, M. Resonant Electron Capture Mass Spectrometry of Free Fatty Acids: Examination of Ion Structures Using Deuterium-Labeled Fatty Acids and Collisional Activation. J. Mass Spectrom. 2002, 37(3), 313-321.

10. Cheng, C.; Pittenauer, E.; Gross, M. L. Charge-Remote Fragmentations Are Energy-Dependent Processes. J. Am. Soc. Mass Spectrom. 1998, 9(8), 840-844.

11. Seto, C.; Grossert, J. S.; Waddell, D. S.; Curtis, J. M.; Boyd, R. K. Effects of Ionization Mode on Charge-Site-Remote and Related Fragmentation Reactions of Long-Chain Quaternary Ammonium Ions. J. Am. Soc. Mass Spectrom. 2001, 12, 571-579. 
12. Fischer, M.; Veith, H. J. Reactions of 2- and 3-Phenyl Substituted Alkylalkylidene Iminium Ions in the Gas Phase. Helv. Chim. Acta 1981, 64(4), 1083-1091.

13. Veith, H. J. Mass Spectrometry of Ammonium and Iminium Salts. Mass Spectrom. Rev. 1983, 2(4), 419-446.

14. Harrison, A. G. Fragmentation Reactions of Alkylphenylammonium Ions. J. Mass Spectrom. 1999, 34(12), 1253-1273.

15. Bosma, N. L.; Harrison, A. G. An Energy-Resolved Study of the Fragmentation Reactions of Alkyl Ammonium Ions. Can. J. Chem. 1994, 72(11), 2205-2211.

16. Katritzky, A. R.; Shipkova, P. A.; Daniel, M. Q.; Nichols, A.; Burton, R. D.; Watson, C. H.; Eyler, J. R.; Tamm, T.; Karelson, M.; Zerner, M. C. Study of Radical Merostabilization by Electrospray FTICR/MS. J. Am. Chem. Soc. 1996, 118, 1190511911.

17. Hau, J.; Stadler, R.; Jenny, T. A.; Fay, L. B. Tandem Mass Spectrometric Accurate Mass Performance of Time-of-Flight and Fourier Transform Ion Cyclotron Resonance Mass Spectrometry: A Case Study with Pyridine Derivatives. Rapid Commun. Mass Spectrom. 2001, 15, 1840-1848.

18. Vernikova, I.; Claeys, M.; Salahub, D. R.; Casida, M. E. Excitation Processes in Alkali-Cationized Esters: A Molecular Orbital Study. Int. J. Mass Spectrom. 2001, 210/211(1-3), 21-30.

19. Aschi, M.; Harvey, J. N. Spin Isomerization of para-Substituted Phenyl Cations. J. Chem. Soc. Perkin Trans. 1999, 2, 1059-1062.

20. Harvey, J. N.; Aschi, M.; Schwarz, H.; Koch, W. The Singlet and Triplet States of Phenyl Cation. A Hybrid Approach for Locating Minimum Energy Crossing Points Between NonInteracting Potential Energy Surfaces. Theor. Chem. Acc. 1998, 99, 95-99.

21. Poutsma, J. C.; Upshaw, S. D.; Squires, R. R.; Wenthold, P. G. Absolute Heat of Formation and Singlet-Triplet Splitting for HCCN. J. Phys. Chem. A 2002, 106, 1067-1073.

22. Wenthold, P. G.; Hu, J.; Squires, R. R. $o^{-}, m^{-}$, and $p$-Benzyne Negative Ions in the Gas Phase: Synthesis, Authentication, and Thermochemistry. J. Am. Chem. Soc. 1996, 118, 11865-11871.

23. Nash, J. J.; Squires, R. R. Theoretical Studies of $o^{-}, m^{-}$, and p-Benzyne Negative Ions. J. Am. Chem. Soc. 1996, 118, 1187211883.

24. Chaquin, P.; Gherbi, A. Structure and Ring Cleavages of the Phosphirane Cation: A Theoretical ab Initio SCF-CI Study. J. Org. Chem. 1993, 58, 1379-1384.

25. Gasper, S. M.; Devadoss, C.; Schuster, G. B. Photolysis of Substituted Benzenediazonium Salts: Spin-Selective Reactivity of Aryl Cations. J. Am. Chem. Soc. 1995, 117, 5206-5211.

26. Zhang, X.; Chen, P. Photoelectron Spectrum of o-Benzyne. Ionization Potentials as a Measure of Singlet-Triplet Gaps. J. Am. Chem. Soc. 1992, 114, 3147-3148.
27. Flammang, R.; Gerbaux, P.; Wah-Wong, M. Identification of Singlet and Triplet SCNO ${ }^{+}$Cations in the Gas Phase: Theory and Experiment. Chem. Phys. Lett. 1999, 300, 183-188.

28. Johnson, M.; Frescas, S.; Oberlender, R. Nichols D. Synthesis and Pharmacological Examination of 1-(3-Methoxy-4-Methylphenyl)-2-Aminopropane and 5-Methoxy-6-Methyl-2-Aminoindan: Similarities to 3,4-(Methylenedioxy)Methamphetamine (MDMA). J. Med. Chem. 1991, 34, 1662-1668.

29. Neumann R.; Abu-Gnim C.; Alkene Oxidation Catalyzed by a Ruthenium-Substituted Heteropolyanion, SiRu W11O39: The Mechanism of the Periodate-Mediated Oxidative Cleavage. I. Am. Chem. Soc. 1990, 112, 6025-6031.

30. Mosse, M; Demarne, H; Filhol, R. Benzamidine Derivatives with Antimicrobial Ativity and Their Use as Disinfecting or Preservative Medicine. Fr. Demande 1985, pp 20. CODEN: FRXXBL FR 2550192 A1 19850208 CAN 103: 104729 AN 1985:504729.

31. Vol'pin, M. E.; Akhrem, I. S.; Kursanov, D. N. Addition of Tropylium Salts to Vinyl Ethers. Zhur. Obshchei Khim. 1960, 30, 159-163.

32. Frisch, M. J.; Trucks, G. W.; Schlegel, H. B.; Scuseria, G. E.; Robb, M. A.; Cheeseman, J. R.; Zakrzewski, V. G.; Montgomery, J. A.; Stratmann, R. E., Jr.; Burant, J. C.; Dapprich, S.; Millam, J. M.; Daniels, A. D.; Kudin, K. N.; Strain, M. C.; Farkas, O.; Tomasi, J.; Barone, V.; Cossi, M.; Cammi, R.; Mennucci, B.; Pomelli, C.; Adamo, C.; Clifford, S.; Ochterski, J.; Petersson, G. A.; Ayala, P.Y.; Cui, Q.; Morokuma, K.; Malick, D. K.; Rabuck, A. D.; Raghavachari, K.; Foresman, J. B.; Cioslowski, J.; Ortiz, J. V.; Baboul, A. G.; Stefanov, B. B.; Liu, G.; Liashenko, A.; Piskorz, P.; Komaromi, I.; Gomperts, R.; Martin, R. L.; Fox, D. J.; Keith, T.; Al-Laham, M. A.; Peng, C. Y.; Nanayakkara, A.; Challacombe, M.; Gill, P. M. W.; Johnson, B.; Chen, W.; Wong, M. W.; Andres, J. L.; Gonzalez, C.; HeadGordon, M.; Replogle, E. S.; Pople, J. A. Gaussian 98. Gaussian, Inc.: Pittsburgh, 1998.

33. Heeren, R. M. A.; Vekey, K. A Novel Method to Determine Collisional Energy Transfer Efficiency by Fourier Transform Ion Cyclotron Resonance Mass Spectrometry. Rapid Commun. Mass Spectrom. 1998, 12(17), 1175-1181.

34. Claereboudt, J.; Claeys, M.; Geise, H.; Gijbels, R.; Vertes, A. Laser Microprobe Mass Spectrometry of Quaternary Phosphonium Salts: Direct Versus Matrix-Assisted Laser Desorption. J. Am. Soc. Mass Spectrom. 1993, 4(10), 798-812.

35. McCrery, D. A.; Peake, D. A.; Gross, M. L. Fast Atom Bombardment and Laser Desorption Mass Spectrometry for Determination of Alkyltriphenyl Phosphonium Salts. Anal. Chem. 1985, 57, 1181-1186. 